\title{
LGI1 encephalitis with squamous lung-cell carcinoma: Resolution after tumor resection
}

Akash Virupakshaiah, MD, Marinos C. Dalakas, MD, Neeja Desai, MD, Scott Mintzer, MD, and Jeffrey Ratliff, MD

Neurol Neuroimmunol Neuroinflamm 2021;8:e905. doi:10.1212/NXI.0000000000000905

\author{
Correspondence \\ Dr. Ratliff \\ Jeffrey.Ratliff@Jefferson.edu
}

Encephalitis with leucine-rich glioma-inactivated-1 (LGI1) immunoglobulin G (IgG) antibodies classically presents with cognitive impairment and characteristic faciobrachial dystonic seizures. ${ }^{1}$ In a murine model, human LGI1 IgG caused reduction of $\mathrm{K}_{\mathrm{v}} 1.1$ channels and $\alpha$-amino-3-hydroxy-5-methyl-4-isoxazolepropionic acid receptor receptors resulting in neuronal hyperexcitability indicating probable pathogenicity of LGI1 antibodies. ${ }^{2}$ LGI1 autoimmunity is associated with malignancy in less than $10 \%$ of cases, including small cell lung cancer, prostate and colon cancer, squamous cell skin carcinoma, and neuroendocrine pancreatic cancer. ${ }^{3,4}$ We present a case of LGI1 encephalitis only partially responsive to immunotherapy with eventual complete resolution after resection of a squamous cell lung carcinoma.

\section{Case report}

A 78-year-old woman was seen for evaluation of worsening cognition and brief spasmodic episodes affecting the arm and face. On examination, she had stereotyped episodes of grimacing and left arm posturing, without impairment of awareness, lasting 2-4 seconds, consistent with faciobrachial seizures. She also had dysarthria, hypophonia, and mild left hand bradykinesia. Her mental status examination showed impaired orientation to our clinic, impairment in delayed recall, and working memory deficits in reversed spelling and serial subtraction tasks.

A brain MRI showed an incidental CSF cyst on the anterior pole of the left lateral ventricle and bilateral subcortical microvascular changes, but no signs of limbic encephalitis. The CSF was normal with only mild protein elevation of $68 \mathrm{mg} / \mathrm{dL}$ and negative for JC virus and neurosyphilis. Continuous EEG monitoring demonstrated no EEG correlation with her dystonic events. She was hyponatremic, with sodium concentrations ranging from $127-132 \mathrm{mmol} / \mathrm{L}$. Initial serologic testing was positive for antibodies to the voltage-gated potassium channel (VGKC) complex $(0.11 \mathrm{nmol} / \mathrm{L})$, but the results did not indicate specific protein targets (i.e., LGI1 or Caspr2). She was treated with high-dose IV immunoglobulin and methylprednisolone, and levetiracetam and clonazepam, but with only partial improvement of her dystonic seizures. She had moderate improvement in her cognitive functioning with partial improvement in delayed recollection and working memory. Follow-up testing for antibody specificity within the VGKC complex by a different laboratory was negative. However, 2 months later, repeated serum tested at the same laboratory using cell-based assay was positive specifically for LGI1.

Seven months after her initial presentation, a CT of the chest showed a right lung mass. Surgical resection demonstrated a moderately differentiated squamous cell carcinoma. After surgery, she had a complete resolution of faciobrachial dystonic seizures; her cognitive dysfunction also resolved, both subjectively and on follow-up examination. All previously applied neurologic therapies were discontinued. She had remained seizure free for over 1 year, through her most recent follow-up.

From the Department of Neurology (A.V., M.C.D., N.D., S.M., J.R.), Thomas Jefferson University, Philadelphia, PA; and Neuroimmunology Unit (M.C.D.), Department of Pathophysiology Faculty of Medicine, National and Kapodistrian University of Athens, Greece.

Go to Neurology.org/NN for full disclosures. Funding information is provided at the end of the article.

The Article Processing Charge was funded by the authors.

This is an open access article distributed under the terms of the Creative Commons Attribution-NonCommercial-NoDerivatives License 4.0 (CC BY-NC-ND), which permits downloading and sharing the work provided it is properly cited. The work cannot be changed in any way or used commercially without permission from the journal. 
To explore the association of her squamous cell lung cancer with encephalitis, we tested sections from her paraffin-embedded tumor tissue for expression of LGI1 antigen. After deparaffinization, rehydration, antigen retrieval, and blocking, as previously described, ${ }^{5}$ the tissue sections were incubated overnight with a commercial rabbit polyclonal antibody against LGI1/EPT (Abcam 30868) $10 \mu \mathrm{g} / \mathrm{mL}$ diluted in 1:20 normal goat serum, followed by rhodamine-conjugated goat anti-rabbit IgG. ${ }^{5}$ Strong staining of many tumor cells was observed (figure, A). Incubation of tumor sections with the same rhodamineconjugated secondary antibody, omitting the primary antiLGI1, showed no staining of tumor cells (figure, B), confirming the specificity of the reaction. Immunostaining with LGI1positive serum from an autoimmune patient with encephalitis diluted at 1:50 also showed that LGI1 was expressed in many tumor cells with a patchy membrane staining (not shown).

Figure Immunohistochemical staining of tumor sections for LGI1 (×40)
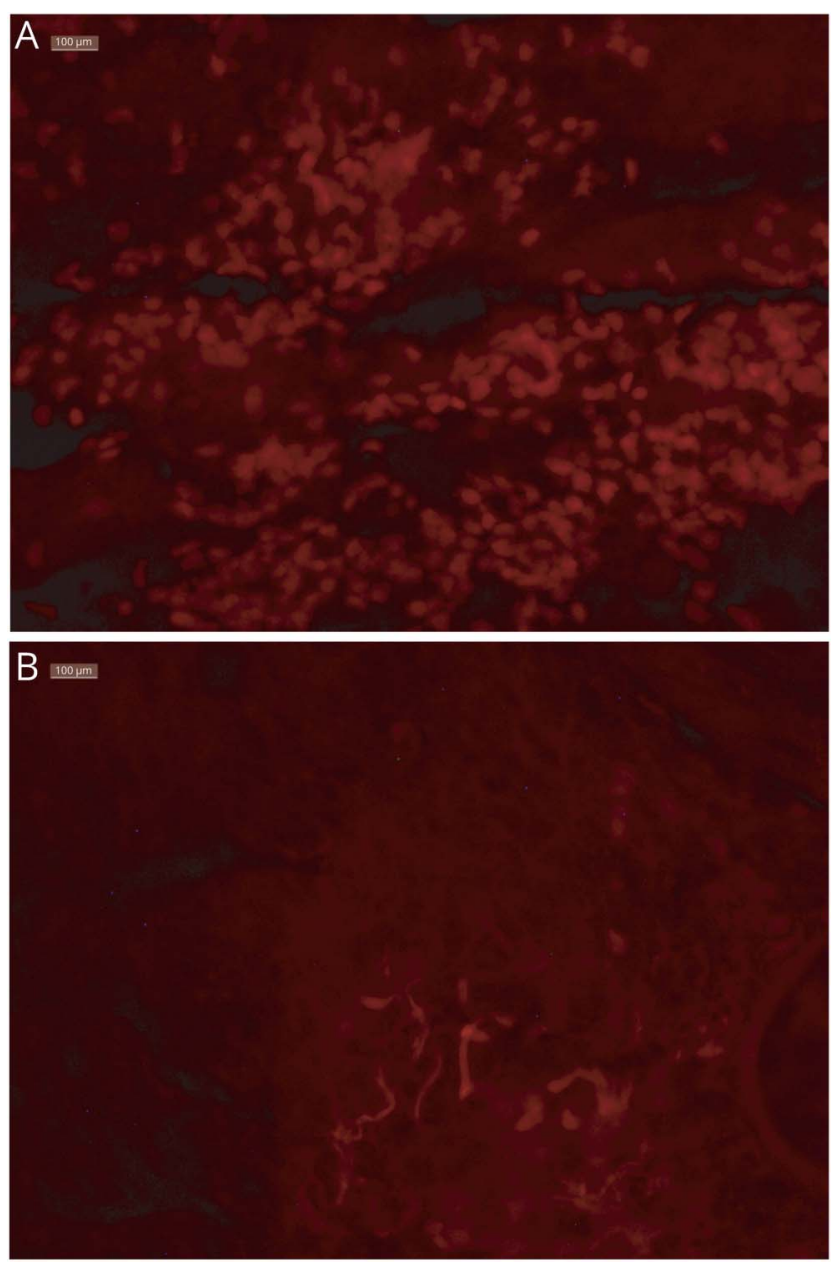

Deparaffinized sections from the patient's tumor immunostained with a commercial polyclonal anti-LGI1 antibody, followed by rhodamine-conjugated secondary antibody ( $A$, top) or only with the same secondary antibody omitting the anti-LGI1 serum (B, bottom). Many LGI1-positive cells (red) are identified within the tumor $(A)$; no tumor cells were stained, other than some connective tissue or vessels with the rhodamine-conjugated secondary antibody alone (B). LGI1 = Leucine-rich glioma-inactivated-1.

\section{Discussion}

We present an association of LGI1 autoimmune encephalitis with squamous cell lung carcinoma with dramatic resolution of all clinical phenomena after surgical resection. The case broadens the spectrum of paraneoplastic association with LGI1 encephalitis and demonstrates that the response to immunotherapy can be insufficient.

Although initial testing for the antibody was negative, the patient eventually tested positive for LGI1 antibodies confirming previous reports that LGI1 antibodies may initially show only seropositivity for antibodies to the VGKC complex. ${ }^{6}$ The connection of the encephalitis to the tumor was strengthened by finding that the tumor strongly expressed LGI1 antigen, although it was unclear which specific tumor cells express LGI1. A study of gene expression in oral squamous cell cancer has shown that LGI1 expression may be elevated in the surrounding mucosa of early squamous cell tumors, perhaps reflecting a mechanism of tumor suppression. ${ }^{7}$ The neurologic autoimmunity developed in our patient likely represents a paraneoplastic mechanism with cross-reactive autoimmunity triggered by LGI1 antigen expression within the neoplastic or the surrounding non-neoplastic tumor cells as supported by the complete resolution of the patient's symptoms after tumor resection.

Although still rare, the association of the typical neurologic phenotype of LGI1 encephalitis with cancer and the complete clinical response to tumor resection suggests an increased need to evaluate for malignancy in future cases, especially when the initial clinical response to immunotherapy is incomplete.

\section{Acknowledgment}

The authors express our appreciation to Sofia Akrivou and Dr. Harry Alexopoulos in Dr. Dalakas's neuroimmunology laboratory for performing the tissue immunostaining. Publication was made possible in part by support from the Thomas Jefferson University Open Access Fund.

\section{Study funding}

No targeted funding reported.

\section{Disclosure}

A. Virupakshaiah reports no relevant disclosures. M. C. Dalakas is an Associate Editor for Neurology ${ }^{\circledR} \mathrm{Neu}-$ roimmunology \& Neuroinflammation. N. Desai reports no relevant disclosures. S. Mintzer reports no relevant disclosures. J. Ratliff is the Deputy Section Editor for Podcasts for the journal Neurology. Go to Neurology.org/NN for full disclosures.

\section{Publication history}

Received by Neurology: Neuroimmunology \& Neuroinflammation December 12, 2019. Accepted in final form September 11, 2020. 


\section{Appendix Authors}

\begin{tabular}{lll}
\hline Name & Location & Contribution \\
\hline $\begin{array}{l}\text { Akash } \\
\text { Mirupakshaiah, }\end{array}$ & $\begin{array}{l}\text { Children's Hospital } \\
\text { of Philadelphia, } \\
\text { Philadelphia, PA }\end{array}$ & $\begin{array}{l}\text { First draft of the manuscript, } \\
\text { background research, and } \\
\text { revision of the manuscript for } \\
\text { intellectual content }\end{array}$ \\
\hline $\begin{array}{l}\text { Marinos C. } \\
\text { Dalakas, MD }\end{array}$ & $\begin{array}{l}\text { Thomas Jefferson } \\
\text { University, } \\
\text { Philadelphia, PA }\end{array}$ & $\begin{array}{l}\text { Revision of the manuscript for } \\
\text { intellectual content, collection } \\
\text { and analysis of } \\
\text { immunohistological data, } \\
\text { generation of figures }\end{array}$ \\
\hline $\begin{array}{l}\text { Neeja Desai, } \\
\text { MD }\end{array}$ & $\begin{array}{l}\text { Raleigh Neurology } \\
\text { Associates, Raleigh, } \\
\text { NC }\end{array}$ & $\begin{array}{l}\text { Revision of the manuscript for } \\
\text { intellectual content }\end{array}$ \\
\hline $\begin{array}{l}\text { Scott Mintzer, } \\
\text { MD }\end{array}$ & $\begin{array}{l}\text { Thomas Jefferson } \\
\text { University, } \\
\text { Philadelphia, PA }\end{array}$ & $\begin{array}{l}\text { Revision of the manuscript for } \\
\text { intellectual content }\end{array}$ \\
\hline $\begin{array}{l}\text { Jeffrey Ratliff, } \\
\text { MD }\end{array}$ & $\begin{array}{l}\text { Thomas Jefferson } \\
\text { University, } \\
\text { Philadelphia, PA }\end{array}$ & $\begin{array}{l}\text { Background research, revised } \\
\text { the manuscript for intellectual } \\
\text { content, and layout of figure }\end{array}$ \\
\hline & & \\
\hline
\end{tabular}

\section{References}

1. Spatola M, Dalmau J. Seizures and risk of epilepsy in autoimmune and other inflammatory encephalitis. Curr Opin Neurol 2017;30:345-353.

2. Petit-Pedrol M, Sell J, Planagumà J, et al. LGI1 antibodies alter K v 1.1 and AMPA receptors changing synaptic excitability, plasticity and memory. Brain 2018;141: 3144-3159.

3. Gadoth A, Pittock SJ, Dubey D, et al. Expanded phenotypes and outcomes among 256 LGI1/CASPR2-IgG-positive patients. Ann Neurol 2017;82:79-92.

4. Alexopoulos H, Dalakas MC. The immunobiology of autoimmune encephalitides. J Autoimmun 2019;104:102339.

5. Alexopoulos H, Dagklis IE, Akrivou S, Bostantjopoulou S, Dalakas MC. Autoimmune encephalitis with GABA-b antibodies, thymoma, and GABA-b receptor thymic expression. Neurol Neuroimmunol NeuroInflammation 2014;1:1-3. doi: 10.1016/j. oraloncology.2007.10.011.

6. Sweeney M, Galli J, McNally S, et al. Delayed LGI1 seropositivity in voltage-gated potassium channel (VGKC)-complex antibody limbic encephalitis. BMJ Case Rep 2017;2017:1-4.

7. Fialka F, Gruber RM, Hitt R, et al. CPA6, FMO2, LGI1, SIAT1 and TNC are differentially expressed in early- and late-stage oral squamous cell carcinoma-a pilot study. Oral Oncol 2008;44:941-948. 


\section{Neurology \\ Neuroimmunology \& Neuroinflammation}

LGI1 encephalitis with squamous lung-cell carcinoma: Resolution after tumor resection Akash Virupakshaiah, Marinos C. Dalakas, Neeja Desai, et al.

Neurol Neuroimmunol Neuroinflamm 2021;8;

DOI 10.1212/NXI.0000000000000905

This information is current as of October 9, 2020

\section{Updated Information \& Services}

References

Subspecialty Collections

Permissions \& Licensing

Reprints including high resolution figures, can be found at:

http://nn.neurology.org/content/8/1/e905.full.html

This article cites 7 articles, 0 of which you can access for free at: http://nn.neurology.org/content/8/1/e905.full.html\#\#ref-list-1

This article, along with others on similar topics, appears in the following collection(s):

All Epilepsy/Seizures

http://nn.neurology.org//cgi/collection/all_epilepsy_seizures

Autoimmune diseases

http://nn.neurology.org//cgi/collection/autoimmune_diseases

Dystonia

http://nn.neurology.org//cgi/collection/dystonia

Paraneoplastic syndrome

http://nn.neurology.org//cgi/collection/paraneoplastic_syndrome

Information about reproducing this article in parts (figures,tables) or in its entirety can be found online at:

http://nn.neurology.org/misc/about.xhtml\#permissions

Information about ordering reprints can be found online:

http://nn.neurology.org/misc/addir.xhtml\#reprintsus

Neurol Neuroimmunol Neuroinflamm is an official journal of the American Academy of Neurology.

Published since April 2014, it is an open-access, online-only, continuous publication journal. Copyright

Copyright $\odot 2020$ The Author(s). Published by Wolters Kluwer Health, Inc. on behalf of the American

Academy of Neurology.. All rights reserved. Online ISSN: 2332-7812.

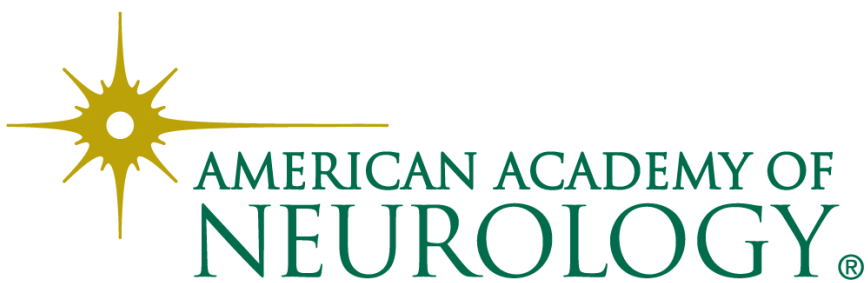

